\title{
CORRESPONDENCE
}

\section{Indian science fails to meet basic needs of the country}

SIR, - Anil Agarwal's article on 'Indian Science' brought out several interesting points. However, he has failed to raise some basic issues. For example, while India is spending money for highly sophisticated technology such as space and nuclear research, science and technology, even in their crudest form, have not reached the mass of Indian villagers, for whom hunger and starvation are an everyday reality. Indian science policy was not able to prevent the Bihar famine and recent floods and cyclone disasters. It has, however, led to the creation of bureaucratic research institutions and to the mushroom growth of CSIR research laboratories. It is, in fact, only the continuation of a policy which existed in colonial times. Research institutions such as CSIR, the Atomic Energy Commission and the Defence Research Laboratories are prestige institutions. Most Government bodies are bureaucratic institutions controlled by a few individuals.

India has built up a sizeable infrastructure for research and industry, but technology for manufacturing common household goods, such as dry batteries or condensed milk, still has to be imported. Indian scientists have given no thought to the need of basic technology in their country. Despite the green revolution, agricultural wages have declined or stagnated in real terms. The population of cities is increasing annually by about $5 \%$ because of the influx of the impoverished from the countryside.

The present attempts to formulate a science policy do not account well enough for education. The type of science education given in Indian universities is imported from western countries, and has no relevance to Indian society. A large amount of money has been spent on universities, research institutions and engineering colleges. At the moment there are more than $3,000,000$ students in universities, more than one third of them being science students. By the end of 1979 the figure will rise to more than $5,000,000$.

Indian universities have become factories for producing graduates. But why expand like this when there are not enough jobs for those who already have degrees? Recently there were more than 40,000 applicants for 40 vacancies; and for a few vacancies in nationalised banks there were so many applications that they had to be collected in vanloads. Unemployment among graduates runs at more than $30 \%$ and in large cities the situation is really alarming. Even though most universities provide undergraduate science and technology courses, the standard is pretty bad. That of science teaching in private colleges (which are affiliated to the universities but run on a commercial basis) is far below normal. Most teachers do not have sufficient qualifications to teach at this level and laboratory facilities are very bad.

What is the point of producing graduates who do not come up to reasonable standards and who do not serve any useful purpose in Indian society? Instead, science education should aim to teach basic ideas on a mass scale. The standard of science teaching in schools must be improved before talking about undergraduate study. Most schools in small towns have to be content with spirit lamps, and experiments are not devised to make maximum use of existing facilities.

It would, for example, be a good idea to use experimental kits (like those devised by the Open University) which could be stored in small towns, each store forming the nucleus of a science centre. Mobile service units, manned by trained teachers and operating from those centres, could go to villages and explain to children, with the help of simple experiments the concepts of basic science and technology. So far Indian science education has no relevance to Indian society.

Although a lot of noise has been made in favour of appropriate technology, it has failed to make any impact on rural development in India. This is because appropriate technology by definition is an indigeneous self-generating process arising as a response to the economic and social needs of various forms and levels of society instigated and initiated by the users of existing technology. Such technologies will not work satisfactorily until farmers have experienced the benefits of communal production and projects and are thus able to design and operate such equipment. Unless the desire for change and for an appreciably higher standard of living takes place in the peasant communities (which is happening among Punjab and Hariyana farmers) new techniques will not be accepted or exploited fully.

At present the keystone of Indian science education is elitism and personal achievement rather than social responsibility; centralisation rather than dispersion; urban rather than rural development; consumption rather than aesthetic development. What is important and essential is that basic science and technology should be oriented towards the needs of the Indian society. Above all, the masses must be carried with technological development and not isolated from it.

$$
\text { Yours faithfully, }
$$

$$
\text { A. VAIDYANATHAN }
$$

The Open University, Milton Keynes, UK

\section{Nuclear secrets}

SIR, - We concur with the sentiment expressed in your editorial Nuclear secrets: no clear frontiers (18 October page 511) that the "narrower question of American security should yield to the broader one of global nonproliferation". But we hope you did not mean that articles about hydrogen bombs should not be published simply because of "sincerely held views" that such articles contribute to proliferation.

Neither of the disputed documents could be of aid to a state in the initial acquisition of nuclear weapons, because the documents discuss thermonuclear weapons, for which a fission weapon capability is a prerequisite. Moreover, most of the dialogue and court proceedings was in the broader context of global non-proliferation.

Months ago, before the temporary restraining order was issued by Judge Warren, we technically reviewed Morland's article for The Progressive. The article and letter do not contain design details; rather they discuss various - oftentimes incorrectly applied concepts already known to scientists throughout the world. It is therefore difficult to understand how such an article can further affect the already precarious international situation we now face.

Technical information is essential to informed political debate on an enormous range of issues. For example, thinking only of current policy debate concerning nuclear weapons and nuclear arms limitation, we might list the following: the SALT treaty, the necessity of the MX missile, its siting alternatives, and a comprehensive nuclear test ban.

The US and other nuclear weapons-states must face the fact that five nations, without help, have successfully undertaken the industrial and scientific effort necessary to make hydrogen bombs. The average length of time to achieve a fusion explosion has been five years after first testing a fission device. That this average was as long as five years is more likely due to political indecision and industrial development time rather than a lack of understanding of elementary concepts.

Motivation and resources are far more important determinants than underlying concepts. It is still prudent for governments to avoid authenticating (through their powers of classification) partially correct public

information, such as the Morland article and various letters. But mainly they should concentrate on protecting their own ultrasensitive official documents containing weapons-design data, for example UCRL -4725 and -5280 , which the US Government erred in making available to the public.

The issues involved in the case go far beyond the question of weapons data alone. For example, the US Government in its brief to the 7th Circuit Court of Appeals in Chicago raised the argument that "technical data"' are not constitutionally protected under the First Amendment because they are not an "essential part of any exposition of ideas" and are not of any "social value as a step to truth". In a world as technologically oriented as ours, such an argument is not only nonsensical and false, it is dangerous to the functioning of free societies.

One of the issues raised by Morland is that unnecessary secrecy can tranquillize public debate. Partly because of reliance on technology-denial and secrecy, several US Administrations have avoided a moratorium on testing, production, or deployment of nuclear weapons - although such restraint would retard proliferation far more substantially than does the illusion of security through technology-denial and secrecy. The most urgent need is a universal nuclear test ban, which might be introduced as an amendment to the Nuclear Non-Proliferation Treaty.

All of the signatories to this letter are engineering physicists who have filed affidavits regarding the various letters and articles relevant to The Progressive case and two of us have had access to the classified and "in camera" documents. This letter has no official connection with the Argonne National Laboratory, with the University of Chicago, nor with the UK Department of Energy. Your faithfully,

GERALDE. MARSH Alexander De Volpi GEORGE S. StANFORD

Argonne National Laboratory, Argonne, Illinois

\section{Exposing sociobiology?}

SIR,-I am pleased to detect a slight shift in Nature's editorial predilections, from totalitarian socialism to totalitarian Mahometism. At least, as Mr Crouchback would say, they have a king and some sort of religion.

Perhaps you will now find it possible to expose the sociobiological theories as no mereappendage of Naziism, but the very emanation of Satan; whose hand can now be discerned - in the horrific decline in spirituality - to say nothing of the savage cuts in public expenditure, and insecurity of tenure in medical research jobs - that has plagued the West since the Turk was stopped at the gates of Vienna.

Your faithfully, Charles W. Clark

Daresbury Laboratory, Daresbury,

Warrington, UK 